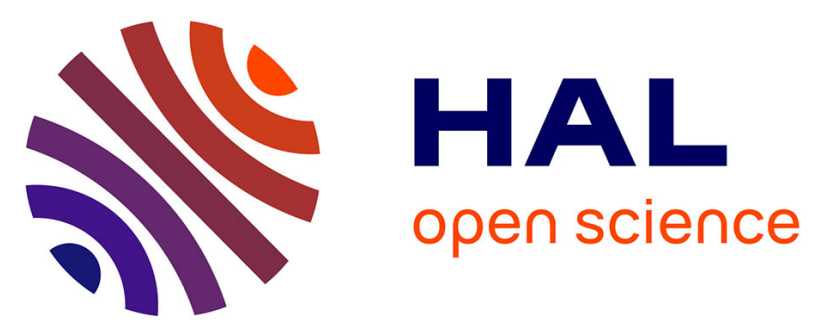

\title{
Carbon sinks in small Sahelian lakes as an unexpected effect of land use changes since the 1960s (Saga Gorou and Dallol Bosso, SW Niger)
}

R. Mabicka Obame, Yoann Copard, David Sebag, Amadou Abdourhamane Touré, Mohammed Boussafir, V. Bichet, Z. Garba, G. Guillon, Ch. Petit, J.L. Rajot, et al.

\section{To cite this version:}

R. Mabicka Obame, Yoann Copard, David Sebag, Amadou Abdourhamane Touré, Mohammed Boussafir, et al.. Carbon sinks in small Sahelian lakes as an unexpected effect of land use changes since the 1960s (Saga Gorou and Dallol Bosso, SW Niger). CATENA, 2014, 114, pp.1-10. 10.1016/j.catena.2013.10.008 . insu-00910180

\section{HAL Id: insu-00910180 https://hal-insu.archives-ouvertes.fr/insu-00910180}

Submitted on 4 Mar 2014

HAL is a multi-disciplinary open access archive for the deposit and dissemination of scientific research documents, whether they are published or not. The documents may come from teaching and research institutions in France or abroad, or from public or private research centers.
L'archive ouverte pluridisciplinaire HAL, est destinée au dépôt et à la diffusion de documents scientifiques de niveau recherche, publiés ou non, émanant des établissements d'enseignement et de recherche français ou étrangers, des laboratoires publics ou privés. 


\section{Carbon sinks in small Sahelian lakes as an unexpected effect of land use changes since the 1960s (Saga Gorou and Dallol Bosso, SW Niger)}

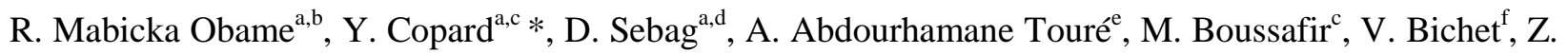
Garba $^{\mathrm{e}}$, R. Guillon ${ }^{\mathrm{g}}$, C. Petit ${ }^{\mathrm{h}}$, J.-L. Rajot ${ }^{\mathrm{i}, \mathrm{j}}$, A. Durand ${ }^{\mathrm{a}}$

${ }^{a}$ Laboratoire M2C, UMR CNRS 6143, University of Rouen, 76821 Mont Saint Aignan, France

${ }^{b}$ Laboratoire URESTE, University of Masuku, Franceville, Gabon

${ }^{c}$ Laboratoire ISTO, UMR CNRS 7327, University of Orléans, 45071 Orléans, France

${ }^{d}$ Laboratoire HydroSciences Montpellier, UMR IRD 5569, University of Ngaoundéré, Cameroun

${ }^{e}$ Department of Earth Sciences, University Abdou Moumouni, Niamey, Niger

${ }^{f}$ Laboratoire Chrono-Environnement, UMR CNRS 6249, University of Franche-Comté, Besançon, France

${ }^{g}$ Laboratoire ArTeHis, UMR CNRS 6298, University of Bourgogne, Dijon, France

${ }^{h}$ Laboratoire ArScAn, UMR CNRS 7041, University of Paris 1, Paris, France

${ }^{i}$ Laboratoire Bioemco, UMR IRD 211, Niamey, Niger

${ }^{j}$ Laboratoire LISA, UMR CNRS 7583, University of Paris-Est Créteil, Créteil, France

\section{Corresponding author}

Dr. Yoann Copard

UMR CNRS 6143 M2C - dpt Earth Sciences and Environment, University of Rouen, 76821 Mont Saint Aignan, France

present address up to 08.31 .2014

UMR CNRS 7327 ISTO, 1A rue de la Férolerie, 45071 Orléans Cedex 2, France

tel.: (33) 238417007 / Fax: (33) 238494476

email: yoann.copard@cnrs-orleans.fr 


\begin{abstract}
For several decades, global change has resulted in an increase in runoff in the Sahelian belt, provoking major changes in the quality and quantity of sediments transported by drainage networks. One of the astonishing consequences is the establishment of numerous permanent lakes. The origins of particulate organic matter $(\mathrm{OM})$ preserved within lacustrine sediments of three lakes were investigated by coupling optical observations (palynofacies) and bulk geochemistry (Rock-Eval 6 pyrolysis). An initial estimate of particulate organic carbon (OC) stored in these lacustrine sediments was assessed. Soil organic matter (SOM) was sampled from the surface $(0-10 \mathrm{~cm})$ of various land-use and land-cover areas and was characterized and compared with sedimentary organic matter. Our results reveal that Lake Tankalawal is subjected to high autochthonous organic sedimentation (TOC ranges between 3.0 and 10.0 wt. \%), while lakes Bangou Kirey and Bi are characterized by weak sedimentation of non-indigenous OM originating from the soil erosion and shore vegetation (TOC $<3.0$ wt. \%). In sediments, the effects of early diagenesis on the OM induce a loss of labile and aquatic OM but also a significant loss of terrestrial OM, which is supposed to be more resistant than its aquatic counterpart. Both the preservation of OM in top sediments and the relative preservation of terrestrial OM impact the OC storage in lakes. Indeed, OC storage in lacustrine sediments (Lake Bangou Kirey) was two to seven times higher than the OC storage in Sahelian soils, where greater contributions of terrestrial OM to sedimentary OM are associated with lower OC storage in lacustrine sediments. For lakes Bangou Kirey and Bi, OC accumulation rates were also assessed; due to the identification of a sedimentary limit corresponding to the establishment of permanent lakes dated earlier 1960s. High OC fluxes were estimated and ranged between 104 and $213 \mathrm{~g}$ OC $\mathrm{m}^{-2} \mathrm{yr}^{-1}$. Compared with other OC accumulation rates for various African lakes, these high values are similar to those calculated for reservoirs and are related to anthropogenic pressure, soil textures favoring erosion, and proper physical and chemical conditions for OM preservation in sediments. Accordingly, in these Sahelian environments that are generally viewed as non-efficient in storing OC, we claim that global change could promote a new OC sink. If other similar studies reinforce our assertion, then regional $\mathrm{C}$ budgets should be revisited.
\end{abstract}


Keywords: particulate organic matter, carbon sink, soil erosion, lakes, Sahel, Global Change

\section{Introduction}

Since the 1960s, Sahel has been subjected to a spectacular climatic shift toward a strong deficit in precipitation with a decrease of 20 to $50 \%$ (e.g., Lebel et al., 2009; l'Hote et al., 2002). Simultaneously, this region has experienced vigorous population growth, from $1.5 \%$ to $3.0 \%$ per year in the period from the 1950s to the 2000s (e.g., Raynaut, 2001, ECOWAS-SWAC / OECD, 2007). The combination of climatic shifts and anthropogenic pressure are responsible for drastic environmental changes in this harsh environment (Niang et al., 2007). Southwestern part of Niger is not exempt from these changes. The increase in runoff, which modified the water budget in watersheds, was broadly examined (e.g., Cappelaere et al., 2009; Descroix et al., 2012; Leblanc et al., 2008). In particular, the causes of this increase in runoff were investigated in the context of changes in land use accompanied by progressive soil crusting. Surprisingly, despite the persistence of desertification, the regional water table, regionally named "le paradoxe de Niamey," has risen (Leduc et al., 1997; 2001). This rise of the water table has involved the establishment of numerous permanent or ephemeral small lakes throughout the Sahelian belt (e.g. Cappeleare et al., 2009; Desconnets et al., 1997).

The intensification of surface runoff due to land use changes have triggered some changes in the budget of sediments within watersheds, which can be expressed by (i) a rise in erosion intensity, (ii) changes in erosion sources and (iii) an increase in sediment accumulation rates in lakes. The increase of cultivated areas implies that there are sediment and nutrient supplies in ponds and lakes (Descroix et al., 2012 and references therein). These changes also affect the quality and the amount of terrestrial organic supplies (allochthonous $\mathrm{OM}$ ) carried by rivers to lakes and the primary organic productivity in lakes (autochthonous OM). Sahelian soils and sediments have been considered as weak C sinks and are poorly 
studied (Feller et al., 1991; Fofana et al., 2008); these recent environmental changes may significantly modify the organic $\mathrm{C}$ budget and exchange between terrestrial and aquatic environments.

The goal of this preliminary study was to focus on these new lacustrine $\mathrm{C}$ reservoirs by proposing the first quantification of OC stocks in lacustrine sediments. For this purpose, three representative lakes of the surrounding of Niamey, showing variable anthropogenic pressures, variable sedimentary dynamics and variable water quality levels were examined. We first characterized the optical and geochemical aspects of the OM to seek its origin, weathered stage and the ability to record these environmental changes. Next, OC stocks in Sahelian sediments were assessed and compared with the surficial Sahelian soil OC (SOC) storage, as well as with the OC storage potential of other African lakes.

\section{Local settings and sampling strategy}

\subsection{Geographic and environmental settings}

The limnic complex of Saga Gorou, including Lakes Bangou Kirey and Bi, and the lake Tankalawal are located in southwestern part of Niger (Fig. 1). The regional climate is semi-arid with yearly precipitation ranges between $400-700 \mathrm{~mm}$ and a potential evapostranspiration of $2500 \mathrm{~mm}$ (D'Amato and Lebel, 1998). The bedrocks consist of unconsolidated material composed of silts and clays from the Tertiary Continental Terminal (Greigert, 1966), and are overlaid by Quaternary eolian sands. These thick sandy deposits cover the valleys and can form dunes over the Continental Terminal plateau. Dry and sandy valley and plateaus are considered as the main geomorphic units in this catchment representing $78 \%$ and $22 \%$ of the surface catchment area respectively. Soils consist in tropical ferruginous soils slightly leached on sands (Cambic Arenosols, IUSS-WRB, 2006) and little evolved tropical soils exhibiting a ferruginous facies (Skeletic Leptosols, IUSS-WRB, 2006) developed on plateaus (Gavaud, 1977). This latter soil type is characterized by a single horizon several decimeters thick and results in the dismantling of the ferruginous armor of the plateaus. These specific conditions ruled the initial vegetation cover and the crop management, which is comprised of three distinct units (d'Herbès and Valentin, 1997): tiger brush 
vegetation is developed on plateaus, whereas arable land and rare fallow overlay sandy soils in valleys. However, the recent changes in land use, particularly in the surrounding of cities, involves a complete disappearance of tiger brush since 2009 and fallows land to the benefit of barren surface on the plateaus, and crop land in the valley, favoring soil crusting (Abdourhamane Touré et al 2010; Descroix et al., 2012). This crusting is also imputable to the increase in eolian and water erosion of sandy soils, which truncate soil profiles up to horizon B.

\subsection{Soil sampling strategy}

Sources of OM in lacustrine sediments can be simplistically described as a melange of OM from the catchment (mainly soils) and OM from aquatic production. It is thus important to perform a representative sampling within the catchment of Saga Gorou taken into account major land-uses and land-covers, corresponding to as many soil and SOM types likely to feed the lake. Accordingly, selected plots were based on a combination between land-use and the two main geomorphic units (see section 2.1). In detail, plots from millet crops and crusted surfaces (Casenave and Valentin, 1992), representative of dry valley and counting for 55\% and 19\% respectively in the total catchment area (Abdourhamane Touré et al., 2010) were sampled. In plateau, the land-cover consists only in crusted surface (22\%).

Referring to numerous studies dealing with SOC topsoil distribution in Sahelian soils (table 1 and references therein), Sahelian topsoils contribute for a large part of the total SOC storage (e.g. Batjes and Sombroek, 1997). In addition, topsoils are likely to be eroded during runoff events so that its OM can join the drainage network and finally the lake and, in this area. In this regard, the first ten centimeters of topsoils were considered according to these three main OM sources and for each of them, two plots were sampled (Fig. 1b). Accordingly, two sampling plots $\left(1 \mathrm{~m}^{2}\right)$ were conducted on plateaus (profile P and PP, 4 samples) and four were conducted in sandy valleys (millet crops: profiles M and MM, 4 samples; crusted surfaces: profiles C and CC, 4 samples). For each sampling, three replicates were made and placed few meters away from others. To ensure the representativeness of organic matter quality, the counterparts of each of these replicates were mixed together. 


\subsection{Lakes}

\subsubsection{Geography and characteristics}

Three lakes were cored: two (lakes Bangou Kirey and $\mathrm{Bi}$ ) belong to the Saga Gorou limnic complex $\left(13^{\circ} 28^{\prime}-13^{\circ} 31^{\prime} \mathrm{N} ; 2^{\circ} 11^{\prime}-2^{\circ} 15^{\prime} \mathrm{E}\right.$; Fig. 1B), which comprises a group of lakes sometimes filled by sand. These lakes are located in some topographic depression within small paleo-valley named Kori of Ouallam that was formerly linked to the Niger River. The third lake, named Tankalawal, is located in another dry

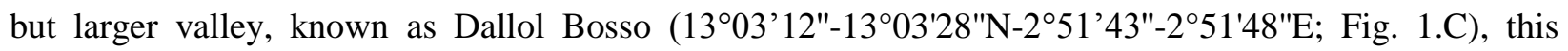
ancient river was an affluent of the Niger river and is now composed by numerous lakes, including Tankalawal.

Lake Bangou Bi (Fig. 1B), occupying $0.06 \mathrm{~km}^{2}$, is oligotrophic and receives detrital input carried out by some gullies (Abdourhamane Touré, 2011) and maximal water depth reaches $3.5 \mathrm{~m}$ during the field study. The catchment $\left(5 \mathrm{~km}^{2}\right)$ is subjected to severe anthropogenic pressure, beginning in earlier 1960s with an extensive development of market crops (millet) to the detriment of natural tiger bush and fallows (Abdourhame Touré et al., 2010). Lake waters show neutral $\mathrm{pH}(\mathrm{pH}=7.75)$ and are mineralized

(conductivity $=275 \mu \mathrm{S} . \mathrm{cm}^{-1}$ ) corresponding to the input of water table. Lake Bangou Kirey (Fig. 1B) is supplied both by the ground water and by a network of gullies that drain an area of $60 \mathrm{~km}^{2}$. Maximal water depth reaches $5.3 \mathrm{~m}$ during the field study and waters are acidic $(\mathrm{pH}=5.6)$, poorly mineralized (conductivity $=30 \mu \mathrm{S} . \mathrm{cm}^{-1}$ ) and exhibit a chlorine to sodic facies. Lake Tankalawal (Fig. 1C) occupies $0.02 \mathrm{~km}^{2}$ and is essentially fed by the ground water able and sediments come from the shore. Maximal water depth reaches $0.2 \mathrm{~m}$ and the water is mesotrophic to eutrophic, basic $(\mathrm{pH}=7.75)$, strongly mineralized (conductivity $=930 \mu \mathrm{S} . \mathrm{cm}^{-1}$ ) and shows a chlorine to sodic facies.

\subsubsection{Sampling design}

In this region of Sahel, most of these permanent lakes occupy the rivers bed of some ancient drainage networks and their impoundment is due to change in land uses and anthropogenic activities (Cappeleare et 
al., 2009; Desconnets et al., 1997). Several arguments, as aerial scenes observations and field enquiries involving local famers (Abdourhamane Touré, 2011, Abdourhamane Touré et al., 2010), tend toward a lakes impoundment starting in 60's. This also corresponds to the strong increase in groundwater resource (+150\%, Leduc et al., 2001). Saga Gorou limnic complex can be considered as a good example of these regional changes in hydrology as it consists of permanent / ephemeral lakes and of lakes fully filled by detrital material. Lake Tankalawal was alse selected because of its organic sedimentation which differs from the Saga Gorou limnic complex. After a bathymetric survey, coring location was selected regarding two conditions: the maximal water depth of the studied lake and being away from detrital fans to avoid coarse material as sand in sediment. For each lake, one core was sampled with a Gravity Corer UWITEC (PVC-liner diameter of $63 \mathrm{~mm}$, with liner length ranges between 100 to $250 \mathrm{~cm}$ ).

Core BB2 from lake Bangou Bi (140 cm length, (133’30"N; $2^{\circ} 12^{\prime} 3^{\prime \prime} \mathrm{E}$, Fig. 1.B) exhibits lithological characteristics have distinguished two sedimentological units: a sandy unit from the bottom of the core to $65 \mathrm{~cm}$ (named unit 1) and unit 2 (from $65 \mathrm{~cm}$ to $0 \mathrm{~cm}$ ), which is silty to loamy. For organic matter analyses, a sampling level of $10 \mathrm{~cm}$ was applied to this core. The core BK-08-02 from the lake Bangou Kirey $\left(13^{\circ} 30^{\prime} 30^{\prime \prime} \mathrm{N}, 2^{\circ} 13 ' 35^{\prime \prime} \mathrm{E}\right.$, Fig. 1.B) exhibits lithological characteristics have distinguished two sedimentological facies: a non-laminated lower unit $(216-120 \mathrm{~cm})$ from the bottom and an upper unit $(120-0 \mathrm{~cm})$ showing an alternating of bright and dark red laminae. Dark laminae consist of alternating bright and dark fine laminae. Six samples, corresponding to the main sedimentary facies observed in this core, were collected in the lower unit (208, 196, 192, 186, 176 and $146 \mathrm{~cm}$ depth) and 3 samples were collected in the upper unit $\left(33.8,32.1\right.$ and $30.5 \mathrm{~cm}$ depth). The core TK1 (130'2' $1^{\prime \prime N}$; $2^{\circ} 51^{\prime} 46^{\prime \prime E}$, Fig. 1) consists of a single unit of $60 \mathrm{~cm}$ length and exhibits loamy sediments. A sampling rate of $5 \mathrm{~cm}$ was applied.

\section{Methods}

\subsection{Geochemistry of sedimentary OM (Rock-Eval 6 pyrolysis)}


Rock-Eval 6 pyrolysis is now widely used for the study of soil OM (e.g., Di-Giovanni et al., 1998, Disnar et al., 2003; Copard et al., 2006; Sebag et al., 2006a) and OM preserved in lacustrine sediments (e.g., DiGiovanni et al., 1998, Noel et al., 2001; Jacob et al., 2004; Hetényi et al., 2010; Boussafir et al., 2012). Pyrolysis was performed using an RE6 pyrolyser (turbo model, Vinci Technologies®, France) on sediment samples that were previously dried at $40^{\circ} \mathrm{C}$ in an air oven and were homogeneously crushed. The first step in this method consists of pyrolysis of an $80-100 \mathrm{mg}$ sample from 200 to $650^{\circ} \mathrm{C}$ under nitrogen with a heating rate of $25^{\circ} \mathrm{C} \cdot \mathrm{min}^{-1}$. Released hydrocarbons were continuously quantified using a Flame Ionization Detector (FID), while $\mathrm{CO}$ and $\mathrm{CO}_{2}$ were quantified using Infra-Red cells. The pyrolysate was then oxidized under air atmosphere from 400 to $750^{\circ} \mathrm{C}$ with a heating rate of $25^{\circ} \mathrm{C} \cdot \mathrm{min}^{-1}$. During this second step, $\mathrm{CO}_{2}$ and $\mathrm{CO}$ were continuously quantified (see also principles in Lafargue et al., 1998). The exploitation of signals derived from the pyrolysis and oxidation stages provides the total organic carbon (TOC, expressed in wt. \%), as well as certain parameters of the quality of organic matter. Among these parameters, particular attention was paid to the amount of hydrocarbon (HC) released during the pyrolysis stage ( $\mathrm{S}_{2}$ signal, expressed in $\mathrm{mg} \mathrm{HC} \cdot \mathrm{g}^{-1}$ sediment), which can also be related to the TOC (HI index, expressed in in $\mathrm{mg} \mathrm{HC} . \mathrm{g}^{-1} \mathrm{TOC}$ ). HI is considered to be a good indicator of the degree of hydrogenation of OM (Lafargue et al., 1998). $\mathrm{S}_{3}$ and $\mathrm{S}_{3^{\prime}}$ signals (expressed in $\mathrm{mg} \mathrm{O}_{2}$. $\mathrm{g}^{-1}$ sediment) reflect the release of $\mathrm{CO}_{2}$ and $\mathrm{CO}$, respectively, during pyrolysis and provide the oxygenation degree of OM (OI index, expressed in $\mathrm{mg} \mathrm{O} \mathrm{O}_{2} \cdot \mathrm{g}^{-1} \mathrm{TOC}$ ). We have also used the $\mathrm{TpS}_{2}$ parameter (expressed in ${ }^{\circ} \mathrm{C}$ ) corresponding to the pyrolysis temperature at which the maximal amount of hydrocarbons is released. This parameter provides information on the degree of transformation recorded by organic components during OM processes (e.g., early diagenesis and pedogenesis) and on the nature of some organic components (e.g., lignin, cellulose, sugars, proteins and humic compounds, see Carrie et al., 2012). In this work, HI vs OI diagram, named pseudo Van Krevelen diagram, was commonly used to highlight the origin of OM and its degradation state (e.g., Disnar et al., 2003). By analyzing pure biochemical and biological standards, as lignin, carbohydrates and phytoplancton, Carrie et al. (2012) have completed the 
interpretation of this diagram by abacus a series of some limit values of HI/OI ratio where these compounds are likely predominant (see Carrie et al., 2012 for further details).

\subsection{Organic petrography (palynofacies method)}

This optical method consists of the study of thin slides of a total assemblage of particulate OM previously isolated from sedimentary rocks using acid digestions (HCl / HF). Initially developed by Combaz (1964), this technic is frequently used for the characterization of particulate OM in lacustrine sediments (e.g., Sifeddine et al., 1995, Noel et al., 2001, Jacob et al., 2004) and in soils (e.g., Sebag et al., 2006b, c, Graz et al., 2010). This approach involves the characterization of different organic constituents showing a large diversity in terms of size, texture, color, opacity and recognizable biological structures (cf. Fig. 2, see also Tyson, 1995 for details). This method provides the origins of the OM (e.g., higher plants or algae), the related production area (bedrocks, soils, or aquatic environments) and the degree of transformation (e.g., during pedogenesis). Here, optical observations and investigations were performed using a DMR XP Leica microscope upon a transmitted light mode, and relative surface quantifications were performed with a 50x objective. A counting of 500 points is required to statistically reflect the abundance of each class of palynofacies. The classification and the characterization of the origin of organic constituents were derived from the work of Tyson (1995), revisited by Sebag et al. (2006c). In this study, phytoclasts consist of (i) ligno-cellulosic (LC) debris showing variable degradation states (from translucent to degraded LC, named TLC and DLC), (ii) opaque particles (OP) obtained either from the incomplete combustion or severe oxidation of LC particles, (iii) gelified particles (GP) originating from an earlier gelification process of $\mathrm{OM}$ inside the higher plant cells under aquatic conditions. In this study, amorphous constituents of organic matter showing diffuse edges with any recognizable biological structures are separated into three classes: (i) brownish AOM with numerous black inclusions (brAOM) originating from bacterial degradation of phytoplanctonic biomass in aquatic environments, (ii) black AOM (blAOM) originating from an organo-mineral matrix with amorphous and LC debris and (iii) reddish AOM classically defined 
as the result of severe pedogenesis of OM. These two latter classes are combined here under the term of terrestrial AOM (TAOM).

\subsection{OC storage and accumulation rates}

In Sahel, deposition environments are scarce and erosion products can be stored in new permanent lakes (Descroix et al., 2012). These new deposit areas can also significantly change the OC budget because lacustrine sediments can contain a significant amount of host OC (i) from aquatic productivity and (ii) from the catchment (SOC). A part of this later OC can be mineralised during OM processes in soils and the remain, escaping from these processes, further deposited in lakes. In this respect, lakes can function as a source and sink of carbon for aquatic OC and as a sink of carbon for SOC. However, any study was hitherto assessed the ability of such lacustrine reservoirs to store OC. Therefore, this study proposes a first estimate of the OC stocks by considering a thickness of $10 \mathrm{~cm}$ of core to compare these stocks with those from neighboring studied soils. OC stocks (OC) were estimated using the following equation:

$$
\text { (1) } \mathrm{OC}=\mathrm{dBD}_{\mathrm{TOC}} \mathrm{t}_{\mathrm{s}}
$$

where dBD represents a measured dry bulk density $\left(\mathrm{g} . \mathrm{cm}^{-3}\right)$ calculated and averaged for each studied sample, after drying at $40^{\circ} \mathrm{C}$ in an air oven; $\mathrm{TOC}_{\mathrm{m}}$, represents the mean TOC value (wt. \%) measured and averaged for each studied sample, and $\mathrm{t}_{\mathrm{s}}$, represents the sediment thickness $(10 \mathrm{~cm}$ in this case). Bulk dry density was measured with a sampling step similar to that used for OM analyses, and then values were then averaged for each core. We have also compared our bulk dry density with those given in equation 2 where TOC is expressed in mg. $\mathrm{g}^{-1}$ (modified from Avnimelech et al., 2001):

$$
\text { (2) } \mathrm{dBD}=1.776-0.363 \log _{\mathrm{e}}\left(\mathrm{TOC}^{*} 10\right)
$$

Average TOC values were assessed by considering the TOC from soils sampled in dry valleys (four profiles, either encrusted or cultivated), and in plateaus (two profiles in barren surfaces).

\section{Results}




\subsection{Bulk organic matter geochemistry}

Rock-Eval 6 parameters are provided according to depth (Fig. 3). Characterization of the OM origin and its degradation states are presented in the figure 4.

Low TOC values, ranging from 0.15 to 0.31 wt. $\%$, characterize the studied soils, with the highest values observed for soils sampled on the plateaus. Other soil profiles such as M, MM, C, and CC contain low TOC, close to $0.15 \mathrm{wt} \%$. These very low values, close to the threshold value with this pyrolyzer and caused by low intensity RE6 signals, imply also a large range of values of HI and OI indices (S2, S3, HI, OI), making their reliable further use difficult (Lafargue et al., 1998). Like TOC values, $S_{2}$ and $S_{3}$ values from these soils are notably low, ranging from 0.07 to $0.34 \mathrm{mg} \mathrm{HC} . \mathrm{g}^{-1}$ sample and 0.14 to $0.20 \mathrm{mg} \mathrm{O}_{2} \mathrm{~g}^{-1}$ sample, respectively. $\mathrm{TpS}_{2}$ values, however, exhibit large variability, with values between $399^{\circ} \mathrm{C}$ and $631^{\circ} \mathrm{C}$

For sediments sampled in the TK1 core, high TOC values increase from the bottom $(1.14 \mathrm{wt} . \%-46 \mathrm{~cm}$ depth) to the top $\left(10.07\right.$ wt. \%). $S_{2}$ and $S_{3}$ parameters displayed the same previous trend with a steady increase toward the top of the core. $S_{2}$ and $S_{3}$ exhibited values ranging from 0.99 to $34.92 \mathrm{mg} \mathrm{HC.} \mathrm{g}^{-1}$ sample and $1.89 \mathrm{mg} \mathrm{O}_{2} \mathrm{~g}^{-1}$ sample to $14.77 \mathrm{mg} \mathrm{O}_{2} \mathrm{~g}^{-1}$ sample, respectively. Toward the top of the core, $\mathrm{TpS}_{2}$ values slightly decreased from 478 to $471^{\circ} \mathrm{C}$.

Within the BB2 core, the two units were also characterized by their different OM content and quality. The lower unit 1 was almost OM free, as TOC values were systematically lower than 0.13 wt. \%. $\mathrm{S}_{2}$ and $\mathrm{S}_{3}$ were very weak, with values lower than $0.03 \mathrm{mg} \mathrm{HC} . \mathrm{g}^{-1}$ sediment and $0.75 \mathrm{mg} \mathrm{O}_{2} \mathrm{~g}^{-1}$ sediment, respectively, whereas $\mathrm{TpS}_{2}$ values decreased from 502 to $456^{\circ} \mathrm{C}$ toward the upper unit 2. Unit 2 provided TOC values ranging from 1.21 to 3.06 wt. \% without any trend correlating with depth. Samples richer in $\mathrm{OM}$ (at 21, 31 and $41 \mathrm{~cm}$ depth) also exhibited higher $S_{2}$ and $S_{3}$, with values ranging from 1.69 et 6.00 $\mathrm{mg} \mathrm{HC} \mathrm{g}{ }^{-1}$ sediment and 2.32 et $6.28 \mathrm{mg} \mathrm{O}_{2} \mathrm{~g}^{-1}$ sediment, respectively. Toward the top of the core, $\mathrm{TpS}_{2}$ values decreased from 456 to $442^{\circ} \mathrm{C}$.

TOC measured in samples from the lower part (0.28 to $0.54 \mathrm{wt} . \%)$ of the BK-08-02 core, where there is an absence of lamina, were lower than those sampled in the upper laminated part of the core (between 
0.69 to 0.78 wt. \%). These lower TOC values were accompanied by lower $S_{2}$ (from 0.12 to 0.18 versus 0.52 to $0.62 \mathrm{mgHC} . \mathrm{g}^{-1}$ sediment in lamina) and also by lower S3 values (2.91 to 3.06 versus 3.91 to 4.25 $\mathrm{mg} \mathrm{O} \mathrm{O}_{2} \mathrm{~g}-1$ sediment in lamina). As a consequence, organic matter in the lamina was more hydrogenated and less oxidized than that preserved in the non-laminated counterpart. $\mathrm{TpS}_{2}$ values are highly variable and generally lower for lamina $\left(404-440^{\circ} \mathrm{C}\right.$ versus $390^{\circ} \mathrm{C}-509^{\circ} \mathrm{C}$ for non-laminated sediment).

\subsection{Organic petrography}

Palynofacies data are presented according to surface particles (Fig. 3) and percent of particles in the total assemblage.

The palynofacies assemblage in the TK1 core was dominated by aquatic OM (58 to $86 \%$ ) consisting of BrAOM (29 to $80 \%$ ) and GP (5 to $36 \%$ ). In contrast with BrAOM, GP tended to decrease toward the surface, where their contribution reached 16 to $36 \%$ in the deepest part but was only 5 to $9 \%$ between 1 $31 \mathrm{~cm}$. The terrestrial contribution consisted of OP (3 to $28 \%$ ) and translucent to degraded LC ( $<1$ to 19 $\%$ ) with a minor TAOM contribution of $<3 \%$. With the exception of the surficial sample $(1 \mathrm{~cm}$ depth), OP decreased toward the surface to the benefit of LC particles. These latter particles were not observed in the last centimeters of the core (41 and $46 \mathrm{~cm})$.

The palynofacies assemblage of the unit $1 \mathrm{BB} 2$ core was mainly composed of particulate OM from the catchment (85 to $98 \%$ ). Of these terrestrial OM, OP (61 to $85 \%$ ) was the main class observed followed by LC debris enriched in DLC (11 to $22 \%$ ) and rare TAOM (maximum of $7 \%$ at $141 \mathrm{~cm}$ ). Only LC debris showed a trend with depth with an increase upward. Except for the deepest sample containing $4 \%$ of BrAOM, GP was the observed class of aquatic particles that accounted for $2-13 \%$ of the total assemblage. Within unit 2, terrestrial particles prevailed in the palynofacies assemblage (25 to $78 \%$ ) and were apportioned between OP (9 to $43 \%$ ), LC debris (10 to $32 \%$ ) and, particularly, the degraded counterparts (5 to $31 \%$ ) and TAOM not exceeding $5 \%$. With the exception of the two first surficial samples, OP particles decreased upward from $43 \%$ at $61 \mathrm{~cm}$ depth to $8 \%$ at $21 \mathrm{~cm}$ depth. TLC particles did not exceed $5 \%$ (at $11 \mathrm{~cm}$ depth) and increased toward the surface, in contrast with DLC (from $31 \%$ 
at $61 \mathrm{~cm}$ depth to $5 \%$ at $11 \mathrm{~cm}$ depth). Aquatic particles consisted of BrAOM, with their contribution reaching a high of $69 \%$ at $21 \mathrm{~cm}$ and dropping below $20 \%$ at $61 \mathrm{~cm}$ depth. Some GD particles were also found and contributed to $2 \%$ at the unit base and reached $13 \%$ at the top of the core.

\section{Discussion.}

\subsection{Soil organic matter}

With TOC values ranging between 0.15 to $0.31 \mathrm{wt} \%$, the soils in this study were poor in organic matter. Nevertheless, such TOC values are consistent with those of various ferruginous Sahelian soils (Tab. 1). These low TOC values can be explained by the absence of litter due to vegetation cover and by the sandy texture of soils, particularly those located in dry valleys (4 profiles, holding the lower TOC values). SOM bearing this OC is likely derived from woody products or carbohydrates, as evidenced by their HI/OI ratio, which is always lower than $1 / 2$ and is accompanied by high $\mathrm{TpS}_{2}$ (Fig. 3, 4; Carrie et al., 2012, Sebag et al., 2006a).

\subsection{Sources of organic matter in Sahelian lakes}

Sedimentary OM in the TK1 core contains a significant aquatic contribution (Fig. 2, 3, 4). In addition, in the upper part of this core $(0-36 \mathrm{~cm})$, the HI/OI ratio is higher than 2 (fig. $4,5 \mathrm{a}, \mathrm{b})$, corroborating the aquatic origin of this OM, which was most likely obtained from chlorophyll (Carrie et al., 2012). In contrast, the two deepest samples had an HI/OI ratio close to or lower than 1, providing evidence of lignocellulosic, carbohydrate or even protein origins of sedimentary OM (Carrie et al., 2012). Accordingly, the aquatic contribution diminishes or is less preserved than its terrestrial counterpart with depth as attested to by the relationship between the HI/OI ratios and those of the aquatic / terrestrial particles from palynofacies (Fig. 5a). This observed progressive decline might be explained by a higher predisposition of aquatic OM to earlier diagenetic processes (e.g., bacterial consummation, oxidation, cf. Meyers, 1997). Nonetheless, the two deepest samples from this core have the same signature as those observed in unit 2 
of the $\mathrm{BB} 2$ core, characterized by a notably low $\mathrm{HI} / \mathrm{OI}$ ratio and an aquatic / terrestrial particles ratio similar to those measured for the TK1 samples (Fig. 5a). Two hypotheses can be merged to explain the distribution of HI/OI ratios: (i) severe oxidation of OM, affecting both aquatic and terrestrial OM, as there is no change in palynofacies ratio or (ii) a local change in the source of sedimentary OM. Additional information can be revealed comparing RE6 ratio with the degraded $(\mathrm{OP}+\mathrm{TAOM}) /$ preserved (TLC+DLC) terrestrial particles ratio (Fig. 5b). Origin of the low HI/OI ratio for these two samples can be explained by a severe degradation of the preserved terrestrial particles. Indeed, TK1 samples are well distributed along a straight line and are not affected by a change in the source of sedimentary OM (Fig. 5b). Earlier diagenesis could explain the distribution of TK1 samples in figures $5 \mathrm{a}, \mathrm{b}$ and had first to affect the aquatic OM by a gelification process (Fig. 3) and, later, the fresh terrestrial particles, as observed previously in Lake Annecy (Noël et al., 2001). Because the OI values exhibit no significant changes with depth (Fig. 4), OM processes would be maintained in an oxygen-free or poorly oxygenated environment and are certainly imputable to microorganisms. This oxygen-depleted environment is frequently promoted by a fine sedimentation (Mayer, 1994) as seen in this core, explaining the high TOC content.

Unit 1 of the BB2 core is depleted in OM (TOC max. $=0.13$ wt. \%) and the little OM present consists of OP whose origin could be severe oxidation of ligno-cellulosic debris (Tyson, 1995). These values should be considered with caution due to the low TOC values; this strong oxidation is also expressed by very high OI values and low to very low HI values (Fig. 4). This significant contribution of terrestrial particles to the OM assemblage (Fig. 5a) for which a large part is altered (Fig. 5b), can easily explain the two indices from RE6 pyrolysis. Several options might explain the geochemical and optical signatures seen in the unit 1. Ligno-cellulosic debris could originate from a paleosoil, which may existing prior to the establishment of this lake, and containing harshly altered OM because the oxidation degree of sedimentary OM from this unit is higher than that of the studied soils (Fig. 4). This soil could have been temporarily flooded, as evidenced by the occurrence of aquatic particles (Fig. 3, 5a). Other possibility would be that unit 1 corresponds to a filling of the lake fed by extremely altered terrestrial OM from the 
catchment and by coarse detrital sediments or that the preservation of highly degraded OM particles comes from a severe impact of earlier diagenesis that affected the more hydrogenated OM particles. According to the particulate OM assemblage (Fig. 3), the RE6 pyrolysis indices, the HI/OI ratio (Fig. 4) and the palynofacies ratio (Fig. 5a), sedimentary OM from unit 2 would correspond to a mélange of terrestrial and aquatic OM. However, if the palynofacies ratio is close to those calculated for the TK1 samples with a lower HI/OI ratio, the aquatic or terrestrial contribution of sedimentary OM from unit 2 is more degraded than its counterpart from TK1 (Fig. 5a). This difference in degradation could be explained by the organic constituents of unit 2 in comparison with OM assemblage from TK1: GD particles are dominant, and BrAOM is rather scarce for the aquatic particles (Fig. 3), while the OP contribution is significantly higher for the terrestrial particles (Fig. 3), explaining the distribution of samples in figure 5b. Two non-exclusive alternatives may be considered to explain the contribution of such particles in this unit and hence their degree of oxidation. First, OM originating from deep soil might constitute a significant portion of the terrestrial source of $\mathrm{OM}$ due to erosion occurring along the shorelines, as there is no observed drainage network. Second, a strong diagenetic processes occurring earlier in unit 2 might also be promoted by coarser sedimentological particles (more silty than the TK1 core). This second possibility would easily explain why TLC particles, which are more sensitive to degradation than DLC particles, never exceed $5 \%$ in this unit. Contrary to the unit 1 base, the significant proportion of aquatic particles and the best preservation of OM observed in unit 2 provide reasonable evidence that the limit of these two units corresponds with the permanent impoundment of Lake Bangou Bi. As seen in section 2.3, this permanent lake would be dated earlier 1960s (Abdourhame Touré, 2011).

The source of sedimentary OM in the BK-08-02 core can only be inferred with the pseudo Van Krevelen diagram (Fig. 4). By comparing with the OM from the two other cores, it is realistic to draw the same conclusions given for unit 1 of the BB2 core (Fig. 4). Accordingly, the OM is highly degraded, remains essentially terrestrial or was subjected to a severe earlier diagenesis.

Studying sedimentary OM from these three lakes can increase understanding of the functioning of Sahelian lakes. Lake Tankalawal may be an excellent example of a permanent lake in which organic 
sedimentation is ruled by significant aquatic production promoted by meso to eutrophic conditions. Within the sediment, earlier diagenesis provokes a continuous degradation of the labile constituents of aquatic $\mathrm{OM}$ and therefore a relative enrichment in resistant OM. In addition, below a certain depth (46 $\mathrm{cm})$, this degradation also affects the labile terrestrial constituents, while the aquatic OM that is still preserved remains more resistant (Fig. 5b). Lake Bangou Bi reflects two distinct contexts. Unit 1 might correspond to a soil located in a depression occasionally flooded (supply of aquatic OM) and in which harshly degraded terrestrial OM from soil erosion is deposited with coarse sedimentological particles. Unit 2 corresponds to sediment deposition in a permanent lake in which a substantial aquatic contribution is mixed with terrestrial OM from shore erosion. Lake Bangou Kirey can be considered as a permanent lake where the essential OM is terrestrial and comes from a catchment that is highly dissected by gullies. A coupling between poorly mineralized waters due to the neighboring soils and strong degradation due to earlier diagenesis may explain the low aquatic productivity and low level of aquatic OM preservation within sediments.

\subsection{Sahelian lakes as an unexpected organic carbon sink?}

This study proposes a first estimate of the OC stocks by considering a thickness of $10 \mathrm{~cm}$ of core to compare these stocks with those from neighboring studied soils. In addition, mean OC accumulation rates were estimated for these Sahelian lakes (Bangou Bi and Bangou Kirey).

\subsubsection{OC stocks in Sahelian soils and lacustrine environments}

For soils from dry valleys (four profiles, either encrusted or cultivated), an apparent dry bulk density of $1.6 \mathrm{~g} \mathrm{~cm}^{-3}$ (Rajot, pers. data) and an average TOC value of $0.15 \mathrm{wt}$. \% were calculated, providing a mean SOC stock of $0.24 \mathrm{~kg} \mathrm{C} \mathrm{m}^{-2}$. For the two profiles sampled in the plateaus covered by tiger brush, an apparent dry bulk density of $1.3 \mathrm{~g} \mathrm{~cm}^{-3}$ (Volkoff et al., 1999) and an average TOC value of 0.24 wt. \% were calculated, providing a mean SOC stock of $0.31 \mathrm{~kg} \mathrm{C} \mathrm{m}^{-2}$. The calculated stocks for the first $10 \mathrm{~cm}$ 
of topsoil (table 1) are in agreement with literature for the Sahelian belt (Buerkert and Lamers, 1999; Batjes, 2001; Fofana et al., 2008). Weak top SOC stocks can be easily explained by a deficient vegetation cover density exacerbated by anthropogenic pressure (e.g., overgrazing and deforestation, Batjes, 2001) leading to a low level of litter production and a potential increase in soil erosion (e.g., Rajot et al., 2001). Lastly, as shown in table 1, sandy and well-drained soils, such as arenosols, are frequently depleted in SOC (e.g., Feller and Beare, 1997; Saiz et al., 2012).

For the lakes, the mean TOC value for TK1 samples $(0-60 \mathrm{~cm}$ depth) reached $4.62 \mathrm{wt} . \%$, and the mean TOC value for unit 2 of the BB2 core $(0-65 \mathrm{~cm}$ depth) was 2.18 wt. \%. For the BK-08-02 core, the occurrence of laminae between $0-120 \mathrm{~cm}$ depths testifies to a continuous sedimentation means that the beginning of a permanent impoundment of the lake is recorded in sediment and corresponds to $120 \mathrm{~cm}$ depth (Abdourhamane Touré, 2011). Therefore, a TOC value of 0.72 wt. \% was calculated and corresponds to the average TOC measured for the three analyzed samples from the upper unit $(0-120 \mathrm{~cm})$. The average dry bulk densities measured and calculated (cf. eq. 2) are $0.75 / 0.68 \mathrm{~g} \mathrm{~cm}^{-3}$ (BB2), $0.43 /$ $0.45 \mathrm{~g} \mathrm{~cm}^{-3}$ (TK1) and $0.60 / 1.06 \mathrm{~g} \mathrm{~cm}^{-3}$ for BK-08-02. Accordingly, the mean OC stocks for $10 \mathrm{~cm}$ thickness are $1.6 / 1.5 \mathrm{~kg} \mathrm{C} \mathrm{m}^{-2}$ (unit 2 from BB2), $2.0 / 2.1 \mathrm{~kg} \mathrm{C} \mathrm{m}^{-2}$ (TK1) and $0.4 / 0.8 \mathrm{~kg} \mathrm{C} \mathrm{m}^{-2}$ for BK08-02. With the exception of the BK-08-02 core and with respect to uncertainties related to the calculation of these stocks, OC storage levels are 3 to 10 times higher than those estimated for the studied soils. The greater the detrital fraction input into the lakes, the lower the storage of OC in lacustrine sediments. Nonetheless, a part of SOC can be deposited in lacustrine sediments and can act as a new reservoir of SOC.

\subsubsection{Accumulation rates of $O C$ in Sahelian lakes}

Based on the assumption that the establishment, and hence the sediment deposition, of the permanent Lake Bangou Bi, began in the 1960s (Abdourhamane Touré, 2011), a mean accumulation rate of OC could be assessed and corresponds to the limit between the two sedimentological units. If the average TOC value is 2.18 wt. \% and the dry bulk density is 0.68 to $0.75 \mathrm{~g} \mathrm{~cm}^{-3}$, considering the thickness of unit 
$2(65 \mathrm{~cm})$, then the accumulation rate would be 193 to $213 \mathrm{~g} \mathrm{OC} \mathrm{m}^{-2} \mathrm{yr}^{-1}$ for a recording time of 50 years. The same reasoning could be applied to the BK-08-02 core if we consider that the beginning of the sediment deposition occurs at the base of the upper laminated unit (i.e., $120 \mathrm{~cm}$ depth) and dates from the earlier 1960s, then the accumulation rate would be 104 to $183 \mathrm{~g} \mathrm{OC} \mathrm{m}^{-2} \mathrm{yr}^{-1}$. With the exception of Lake Turkana, these rates would be higher than those in literature for other African lakes (Tab. 2). Nevertheless, such rates are of the same order of magnitude as those calculated for ponds or artificial reservoirs devoted to aquaculture (see values and references in Table 2). Non-exclusive assumptions could be evoked the high accumulation rates estimated in these Sahelian lakes:

1- First, soil erosion affects cultivated areas that are regularly fed by manure or other fertilizers, delivering some nutrients to the water column (Leblanc et al., 2008). Combined with a high water temperature, these nutrients would favor good primary aquatic production - which is subsequently subjected to mineralization in the water column or in sediment, as observed for the studied lakes - a major parameter governing the OC accumulation in sediments (Hedges and Keil, 1995). This finding would explain why the estimated rates are higher than those for aquaculture reservoirs.

2- Sahelian catchments frequently consist of sandy and erodible soils and can be aggravated by anthropogenic activities (i.e., culture and pasture, Leblanc et al., 2008; Cappelaere et al., 2009). This high level of detritus might explain why sediment accumulation is also high, a parameter which could promote the OC preservation in sediments (Hedges and Keil, 1995).

However, caution should be paid regarding our estimate, as the OC accumulation rate is based only on 50 years, which is a very short time compared to other natural lakes listed in table 2 . Yet, an increase in the investigation timescale necessarily involves recording some environmental changes, either climatic (drought) or anthropogenic (reforestation, river management), acting as a negative feedback for sediments and OC accumulation rates. In addition, table 2 gathers a panel of values provided by different studies with different approaches (e.g., measurements versus modeling) with different uncertainties for estimating these rates. The differences in uncertainty factors need to be considered when comparing our rates with those from the literature. 


\section{Conclusions}

The main originalities of this work are (i) the distinction of OM sources (aquatic versus terrestrial) preserved in Sahelian lacustrine sediments and (ii) a pioneering assessment of the ability of such lakes to store OC. If further studies provide additional evidence of OC storage within Sahelian lakes, it will be reasonable to conclude that these new lacustrine environments can act as a carbon sink at a regional scale. For these three lakes, OM sources, their contribution and preservation within lacustrine sediments and the related TOC contents of sediments are highly dependent on (i) physical and chemical conditions prevailing in the water column, (ii) sediment particle sizes and (iii) the importance of the detrital input from the shore or from the catchments. For the latter parameter, following a conventional rule, the greater the input of detrital material to the lakes, the lower the storage, and preservation of OC will be in lacustrine sediments. In addition, OM characterization has helped to define - and confirm - the sedimentological limit of the settling of the permanent Lake Bangou Bi (unit 2).

This study presents the first assessment of OC stock and related accumulation rates with a perspective on OC storage in studied soils. SOC stocks are commonly low in the abundant literature, but those estimated for these Sahelian lakes are surprisingly high, and OC accumulation rates are close to rates for ponds or reservoirs devoted to aquaculture. Clearly, these preliminary results have to be verified by other similar studies on a large set of representative lakes disseminated in the Sahelian belt. The results from such regional studies could subsequently be used to re-estimate regional OC budgets and stocks in this environment, which is highly sensitive to global change.

\section{Acknowledgments}

This study was supported (1) by the AIRD (Inter-Institutions Agency for Research and Development) through the CORUS 2 project entitled "Impact de la pression anthropique et du Changement Global sur 
les flux sédimentaires en zone sahélienne" (grant $\mathrm{n}^{\circ}$ 6116) and (2) by the French scientific national program EC2CO - CYTRIX (CNRS / INSU) entitled "Impacts climatiques et anthropiques sur les milieux tropicaux: marqueurs organiques de l'érosion, des flux sédimentaires et de l'évolution des paysages (Niger, Cameroun, Gabon)". Additional funding was provided by the SFR 4116 SCALE (ESTER project) through the AMEDE (Analyse Multi-Echelle de la Dynamique Eolienne au Sahel) and the OMARD tasks (Organic MArker Dynamics in tropical terrestrial environments).

\section{References}

Abbot, M.B., Binford, M.W., Brenner, M., Kelts, K.R., 1997. A $3500{ }^{14}$ C yr High-Resolution Record of Water-Level Changes in Lake Titicaca, Bolivia/Peru. Quaternary Res. 47, 169-180.

Abdourhamane Toure, A. 2011. Erosion en milieu sableux cultivé au Niger : dynamique actuelle et passée en liaison avec la pression anthropique et les changements climatiques. Doctoral thesis, University of Bourgogne, Dijon, 234 p.

Abdourhamane Toure, A., Guillon, R., Garba, Z., Rajot, J.L., Petit, C., Bichet, V., Durand, A., Sebag, D., 2010. Evolution des paysages sahéliens au cours des six dernières decennies dans la région de Niamey : de la disparition de la brousse tigrée à l'encroutement de surface des sols. Pangea, 47-48, 35-40.

Avnimelech, Y., Ritvo, G., Meijer, L.E., Kochba, M. 2001. Water content, organic carbon and dry bulk density in flooded sediments. Aquacult. Eng. 25, 25-33.

Barton, C.E., Torgersen, T., 1988. Paleomagnetic and ${ }^{210} \mathrm{~Pb}$ estimates of sedimentation in lake Turkana, East Africa. Palaeogeogr. Palaeocl. 68, 5360. 
Batjes, N.H., 2001. Option for increasing carbon sequestration in West African soils: an exploratory study with special focus in Senegal. Land Degrad. Dev. 12, 131-142.

Batjes, N.H, Sombroek, W.G., 1997. Possibilities for carbon sequestration in tropical and subtropical soils. Gobal Change Biol. 3, 161-173

Boussafir, M., Sifeddine, A., Jacob J., Foudi, M. Cordeiro, R.C., Albuquerque, A.L.S., Abrao, J.J., Turcq, B., 2012. Petrographical and geochemical study of modern lacustrine sedimentary organic matter (Lagoa do Caçò, Maranão, Brazil): Relationship between early diagenesis, organic sedimentation and lacustrine filling. Org. Geochem. 47, 88-98.

Boyd, C.E., Wood, C.W., Chaney, P.L., Queiroz, J.F., 2010. Role of aquaculture pond sediments in sequestration of annual global carbon emissions. Environ. Pollut. 158, 2537-2540.

Buerkert, A, Lamers, J.P.A., 1999. Soil erosion and deposition effects on surface characteristics and pearl millet growth in the West African Sahel. Plant Soil 215, 239-253.

Cappelaere, B., Descroix, L., Lebel, T., Boulain, N., Ramier, D., Laurent, J.P., Favreau, G., Boubkraoui, S., Boucher, M., Bouzou Moussa, I., Chaffard, V., Hiernaux, P., Issoufou, H.B.A., Le Breton, E., Mamadou, I., Nazoumou, Y., Oi, M., Ottlé, C., Quantin, G., 2009. The SW Niger site of the AMMACATCH observing system: strategy, implementation and site description. J. Hydro. 375, 34-51.

Carrie, J., Sanei, H., Stern, G., 2012. Standardization of Rock-Eval pyrolysis for the analysis of recent sediments and soils. Org. Geochem. 46, 38-53. 
Casenave, A., Valentin, C., 1992. A runoff capability classification-system based on surface-features criteria in semiarid areas of Western Africa. J. Hydrol. 130, 231-249.

Combaz, A., 1964. Les palynofacies. Rev. Micropaleontologie, 7, 205-218.

Copard, Y., Di-Giovanni, C., Martaud, T., Albéric, P., Olivier, J.E., 2006. Using Rock-Eval 6 pyrolysis for tracking fossil organic carbon in modern environments : implications for the roles of erosion and weathering. Earth Surf. Proc. Land. 31, 135-153.

D'Amato, N, Lebel, T., 1998. On the characteristics of the rainfall events in the Sahel with a view to the analysis of climatic variability. Int. J. Climatol. 18, 955-974.

Dean, W., Gorham, E., 1998. Magnitude and significance of carbon burial in lakes, reservoirs, and peatlands. Geology 26, 6, 535-538.

Desconnets, J.C., Taupin, J.D., Lebel, T., Leduc, C., 1997. Hydrology of the Hapex-Sahel Central supersite: surface water drainage and aquifer recharge through the pool systems. J. Hydrol 188-189, 155-178.

Descroix L., Laurent J.P., Vauclin M., Amogu O., Boubkraoui S., Ibrahim B., Galle S., Cappelaere B., Bousquet S., Mamadou I., Le Breton E., Lebel T., Quantin G., Ramier D., Boulain N., 2012. Experimental evidence of deep infiltration under sandy flats and gullies in the Sahel. J. Hydro. 424-425, $1-15$.

D’Herbès, J.M., Valentin, C., 1997. Land surface conditions of the Niamey region: ecological and hydrological implications. J. Hydrol. 188-189, 18-42. 
Di-Giovanni, C., Disnar, J.R., Bichet, V., Campy, M., Guillet, B., 1998. Geochemical characterization of soil organic matter and variability of a postglacial detrital organic supply (Chaillexon lake, France). Earth Surf. Proc. Land. 23, 1057-1069.

Disnar, J.R., Guillet, B., Keravis, D., Di-Giovanni, C., Sebag, D., 2003. Soil organic matter (SOM) characterization by Rock-Eval pyrolysis: scope and limitations. Org. Geochem. 34, 327-343.

Downing, J.A., Cole, J.J., Middelburg, J.J., Striegl, R.G., Duarte, C.M., Kortelainen, P., Prairie, Y.T., Laube, K.A., 2008. Sediment organic carbon burial in agriculturally eutrophic impoundments over the last century. Global Biogeochem. Cycle 22, doi:10.1029/2006GB002854.

ECOWAS-SWAC / OECD, 2007. Demographic trend. Atlas on regional integration in West Africa. Population series, Paris, 16p. http://www.oecd.org/swac/publications/39802965.pdf.

Einsele, G., Yan, J., Hinderer, M., 2001. Atmospheric carbon burial in modern lake basins and its significance for the global carbon budget. Global Planet. Change 30, 167-195.

Elberling, B., Touré, A., Rasmussen, K., 2003. Changes in soil organic matter following groundnut-millet cropping at three locations in semi-arid Senegal, West Africa. Agr. Ecosyst. Environ. 96, 37-47.

Farage, P.K., Ardö, J., Olsson, L., Rienzi, E.A., Ball, A.S., Pretty, J.N., 2007. The potential for soil carbon sequestration in three tropical dryland farming systems of Africa and Latin America: A modeling approach. Soil Till. Res. 94, 457-472.

Feller, C., Beare, M.H., 1997. Physical control of soil organic matter dynamics in the tropics. Geoderma 79, 69-116. 
Feller, C., Fritsch, E., Poss, R., Valentin, C., 1991. Effets de la texture sur le stockage et la dynamique des matières organiques dans quelques sols ferrugineux et ferrallitiques (Afrique de l’Ouest, en particulier). Cah. ORSTOM, sér. Pédol. 26, 25-36.

Fofana, B., Wopereis, M.C.S., Bationo, A., Breman, H., Mando, A., 2008. Millet nutrient use efficiency as affected by natural soil fertility, mineral fertilizer use and rainfall in the West African Sahel. Nutr. Cycl. Agroecosys. 81, 25-36.

Gavaud, M., 1977. Les grands traits de la pédogenèse au Niger méridional. Travaux et documents de l'ORSTOM 76, 102 pp.

Giresse, P., Makaya-Mvoubou, 2010. Sediment and particulate organic carbon fluxes in various lacustrine basins of tropical Africa and in the Gulf of Guinea. Global Planet. Change 72, 341-355.

Giresse, P., Maley, J., Brenac, P., 1994. Late Quaternary palaeoenvironments in the Lake Barombi Mbo (West Cameroon) deduced from pollen and carbon isotopes of organic matter. Palaeogeogr., Palaeocl. $107,65-78$.

Graz, Y., Di-Giovanni, C., Copard, Y., Laggoun-Défarge, F., Boussafir, M., Lallier-Vergès, E., Baillif, P., Perdereau, L., Simonneau, A., 2010. Quantitative palynofacies analysis as a new tool to study transfers of fossil organic matter in recent terrestrial environments. Int. J. Coal Geol. 84, 49-62.

Greigert, J., 1966. Description des formations crétacées et tertiaires du bassin des Iullemmeden (Afrique occidentale). Publ. Dir. Mines et Géol. Rép. du Niger 2, 234 p. 
Haefele, S.M., Wopereis, M.C.S., Schloebohm, A.M., Wiechmann, H., 2004. Long-term fertility experiments for irrigated rice in the West African Sahel: effect on soil characteristics. Field Crop. Res. 85, $61-77$.

Hedges, J.I., Keil, R.G., 1995. Sedimentary organic matter preservation: an assessment and speculative synthesis. Mar. Chem. 49, 81-115.

Hetényi, M., Nyilas, T., Sajgó, C.S., 2010. Organic geochemical evidence of late Pleistocene-Holocene environmental changes in the Lake Balaton region (Hungary). Org. Geochem. 41, 915-923.

L'Hôte, Y., Mahé, G., Some, B., Triboulet, J.P., 2002. Analysis of Sahelian annual rainfall index from 1896 to 2000: the drought continues. Hydrol. Sci. J. 47, 563-572.

IUSS Working Group WRB. 2006. World reference base for soil resources 2006. World Soil Resources Reports 103. FAO, Rome.

Jacob, J., Disnar, J.R., Boussafir, M., Sifeddine, A., Albuquerque, A.L.S., Turcq, B., 2004. Major environmental changes recorded by lacustrine sedimentary organic matter since the Last Glacial Maximum under the tropics (Lagoa do Caçó, NE Brazil). Palaeogeogr., Palaeocl., 205, 183-197.

Kunz, M.J., Anselmetti, F.S., Wüest, A., Wehrli, B., Vollenweider, A., Thüring, S., Senn, D.B., 2011. Sediment accumulation and carbon, nitrogen, and phosphorus deposition in the large tropical reservoir Lake Kariba (Zambia/Zimbabwe). J. Geophys. Res., 116, G03003, doi:10.1029/2010JG001538.

Lafargue, E., Marquis, F., Pillot, D., 1998. Rock-Eval 6 applications in hydrocarbon exploration, production and soil contamination studies. Rev. I. Fr. Petrol. 53, 4, 421-437. 
Lebel, T., Cappelaere, B., Galle, S., Hanan, N., Kergoat, L., Levis, S., Vieux, B., Descroix, L., Mougin, E., Peugeot, C., Séguis, L., 2009. AMMA-CATCH studies in the Sahelian region of West-Africa: an overview. AMMA-CATCH Special Issue. J. Hydrol. 375, 3-13.

Leblanc, M., Favreau, G., Massuel, S., Tweed, S., Loireau, M., Cappelaere, B., 2008. Land clearance and hydrological change in the Sahel: SW Niger. Global Planet. Change 61, 135-150.

Leduc, C., Bromley, J., Schroeter, P., 1997. Water table fluctuation and recharge in semi-arid climate: some results of the HAPEX-Sahel hydrodynamic Survey (Niger). J. Hydrol. 188-189, 123-138.

Leduc, C., Favreau, G., Shroeter, P., 2001. Long term rise in a Sahelian water table: the Continental Terminal in South West Niger. J. Hydrol. 243, 43-54.

Lufafa, A., Diédhiou, I., Samba, S.A.N., Séné, M., Khouma, M., Kizito, F., Dick, R.P., Dossa, E., Noller, J.S., 2008. Carbon stocks and patterns in native shrub communities of Senegal's Peanut Basin. Geoderma $146,75-82$.

Malam Issa, O., Le Bissonnais, Y., Défarge, C., Trichet, J., 2001. Role of a cyanobacterial cover on structural stability of sandy soils in the Sahelian part of western Niger. Geoderma 101, 15-30.

Mayer, L.M., 1994 Surface area control of organic carbon accumulation in continental shelf sediments. Geochim.Cosmochim. Acta 58, 1271-1284.

Meyers, P.A., 1997. Organic geochemical proxies of paleoceanographic, paleolimnologic and paleoclimatic processes. Org. Geochem. 27, 213-250. 
Mulholland, P.J., Elwood, J.W., 1982. The role of lake and reservoir sediments as sinks in the perturbed global carbon cycle: Tellus, 34, 490-499.

Niang, B.M.I., Nyong, A., Vogel, C., Githeko, A., Medany, M., Osman-Elasha, B., Tabo, R., Yanda, P., 2007. Africa. Climate Change 2007: Impacts, Adaptation and Vulnerability. Contribution of Working Group II to the Fourth Assessment Report of the Intergovernmental Panel on Climate Change, Parry, M.L., Canziani, O.F., Palutikof, J.P., van der Linden, P.J., Hanson, C.E. (Eds.), Cambridge University Press, Cambridge, pp. 433-467.

Noël, H., Brauer, A., Garbolino, E., Lallier-Vergès, E., de Beaulieu, J.L, Disnar, J.R., 2001. Sedimentary organic matter as a marker of soil erosion during the last millenia (Annecy Lake). J. Paleolimnol. 25, 229244.

Pasche, N., Alunga, G., Mills, K., Muvundja, F., Ryves, D.B., Schurter, M., Wehrli, B., Schmid, M., 2010. Abrupt onset of carbonate deposition in lake Kivu during 60's: response to recent environmental changes. J. Paleolimnol. 44, 931-946.

Rajot, J.L., Alfaro, S.C., Gomes, L., Gaudichet, A., 2003. Soil crusting on sandy soils and its influence on wind erosion. Catena 53, 1-16.

Raynaut, C., 2001. Societies and nature in the Sahel: ecological diversity and social dynamics. Global Environ. Change 11, 9-18.

Ringius, L., 2002. Soil carbon sequestration and the CDM: opportunities and challenges for Africa. Climatic Change 54, 471-495. 
Saiz, G., Bird, M.I., Domingues, T., Schrodt, F., Schwarz, M., Feldpausch, T.R., Veenendaal, E., Djagbletey, G., Hien, F., Compaoré, H., Diallo, A., Lloyd, J., 2012. Variation in soil carbon stocks and their determinants across a precipitation gradient in West Africa. Global Change Biol. 18, 1670-1683.

Sebag, D., Disnar, J.R., Guillet, B., Di-Giovanni, C., Verrecchia, E.P., Durand, A., 2006a. Monitoring organic matter dynamics in soil profiles in Rock-Eval pyrolysis: bulk characterization and quantification of degradation. Eur. J. Soil Sci. 57, 344-355.

Sebag, D., Di-Giovanni, C., Ogier, S., Mesnage, V., Laggoun-Défage, F., Durand, A., 2006b. Inventory of sedimentary organic matter in modern wetland (Marais Vernier, Normandy, France) as sourceindicative tools to study Holocene alluvial deposits (Lower Seine Valley, France). Int. J. Coal Geol. 67, $1-16$.

Sebag, D., Copard, Y., Di-Giovanni, C., Durand, A., Laignel, B., Ogier, S., Mesnage, V., 2006c. Palynofacies as useful tool to study origins and transfers of particulate organic matter in recent terrestrial environments: Synopsis and prospects. Earth Sci. Rev. 79, 241-259.

Sifeddine, A., Bertrand, P., Lallier-Vergès, E., Patience, A.J., 1995. Organic sedimentation and its Relationship with environmental changes over the last 30,000 years (Lac du Bouchet, Haute-Loire, France). Comparison with other palaeoclimatic lacustrine examples. In: Lallier-Vergès, E Tribovillard, N., Bertrand P. (Eds.), Organic matter accumulation. Lecture Notes in Earth Sciences, 57, pp. 157-168.

Stoof-Leichsenring, K.R., Junginger, A., Olaka, L.A., Tiedemann, R., Trauth, M.H., 2011. Environmental variability in Lake Naivasha, Kenya, over the last two centuries. J. Paleolimnol. 45, 353-367 
Takimoto, A., Nair, V.D., Nair, P.K.R., 2009. Contribution of trees to soil carbon sequestration under agroforestry systems in the West African Sahel. Agroforest. Syst. 76, 11-25.

Tschakert, P., Khouma, M., Sène, M., 2004. Biophysical potential for soil carbon sequestration in agricultural systems of the Old Peanut Basin of Senegal. J. Arid. Environ. 59, 311-333.

Turcq, B., Albuquerque, A.L.S., Cordeiro, R.C., Sifeddine, A., Simoes Filho, F.F.L., Souza, A.G., Abrao, J.J., Oliveira, F.B.L., Silva, A.O., Capitâneo, J., 2002. Accumulation of organic carbon in five Brazilian lakes during the Holocene. Sed. Geol. 148, 319-342.

Tyson, R.V., 1995. Sedimentary organic matter: organic facies and palynofacies. ed. Chapman \& Hall, London.

Verschuren, D., 1999. Influence of depth and mixing regime on sedimentation in a small, fluctuating tropical soda lake. Limnol. Oceanogr. 44, 4, 1103-1113.

Volkoff, B., Faure, P., Dubroeucq, D., Viennot, M., 1999. Estimation des stocks de carbone dans les sols du Bénin. Etude et Gestion des sols 6, 115-130.

Woomer, P.L., Touré, A., Sall, M., 2004. Carbon stocks in Senegal's Sahel Transition Zone. J. Arid Environ. 59, 499-510. 


\section{figures captions}

Figure 1. Geographic context of the studied site and samples location.

Figure 2. Main organic particles observed in BB2 and TK1 cores. Palynofacies classification derives from the review of Sebag et al. (2006c).

Figure 3. Rock-Eval 6 parameters and palynofacies evolution with depth for the BB2 and TK1 cores. $\mathrm{S}_{3}+\mathrm{S}_{3^{\prime}}$ correspond respectively to the release of $\mathrm{CO} 2$ and $\mathrm{CO}$ during pyrolysis stage. Unit 1 from $\mathrm{BB} 2$ core is depleted in OC content (relevance threshold for TOC $=0.15$ wt. \%); however $S_{2}, S_{3}+S_{3^{\prime}}$ and $\mathrm{TpS}_{2}$ are given for information only (for the BB2 core, no particle counting was made at $51 \mathrm{~cm}$ depth since there is no sufficient quantity of sample. The core BK-08-02 is not shown in this figure because of data limitations.

Figure 4. Pseudo Van-Krevelen diagram of soil and lacustrines sediments samples. With reference to the Van Krevelen diagram (i.e. $(\mathrm{H} / \mathrm{C})_{\text {at. }}$ vs $(\mathrm{O} / \mathrm{C})_{\mathrm{at}}$ ), this diagram provides a rapid evaluation of origin of organic matter and its degraded stage defined by an increase in OI and a decrease in HI values respectively. Doted lines correspond respectively to the HI/OI ratio delimiting the main organic constituents (see Carrie et al., 2012 for further details).

Figure 5. (a): $\mathrm{HI} / \mathrm{OI}$ (or $\mathrm{S}_{2} /\left(\mathrm{S}_{3}+\mathrm{S}_{3^{\prime}}\right)$ ) plotted with the palynofacies ratio between aquatic OM particles $(\mathrm{BrAOM}+\mathrm{GP})$ and terrestrial OM particles $(\mathrm{OP}+\mathrm{TAOM}+(\mathrm{TLC}+\mathrm{DLC}$, i.e. ligno-cellulosic debris $))$. (b): HI/OI (or $\mathrm{S}_{2} /\left(\mathrm{S}_{3}+\mathrm{S}_{3^{\prime}}\right)$ ) versus a palynofacies ratio between preserved terrestrial $\mathrm{OM}$ particles $(\mathrm{TLC}+\mathrm{DLC})$ and degraded terrestrial OM particles (OP + TAOM). Signification of symbols is referred to figure 4 and number corresponds to the depth. 

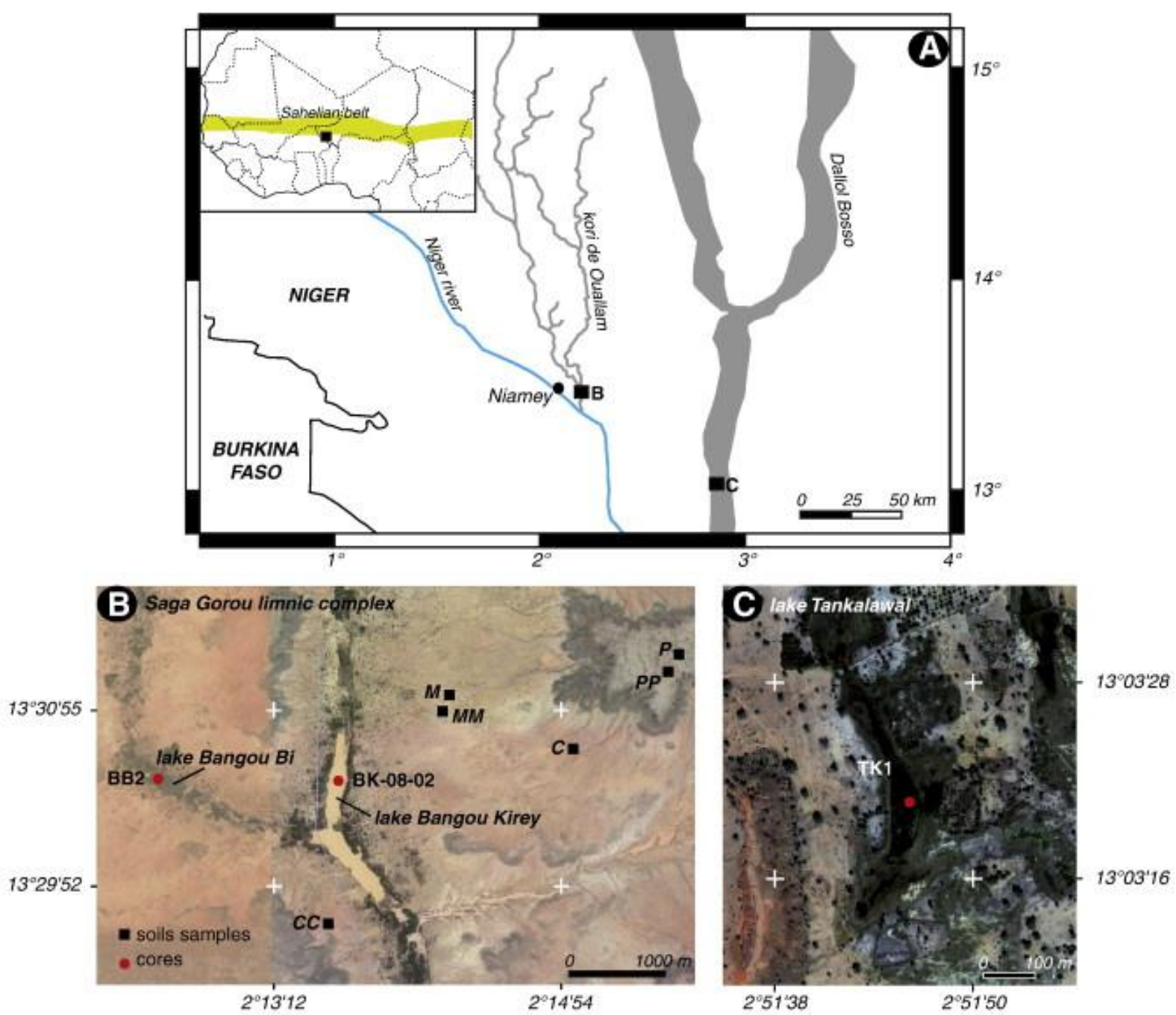

Fig. 1. : Geographic context of the studied site and samples location. 


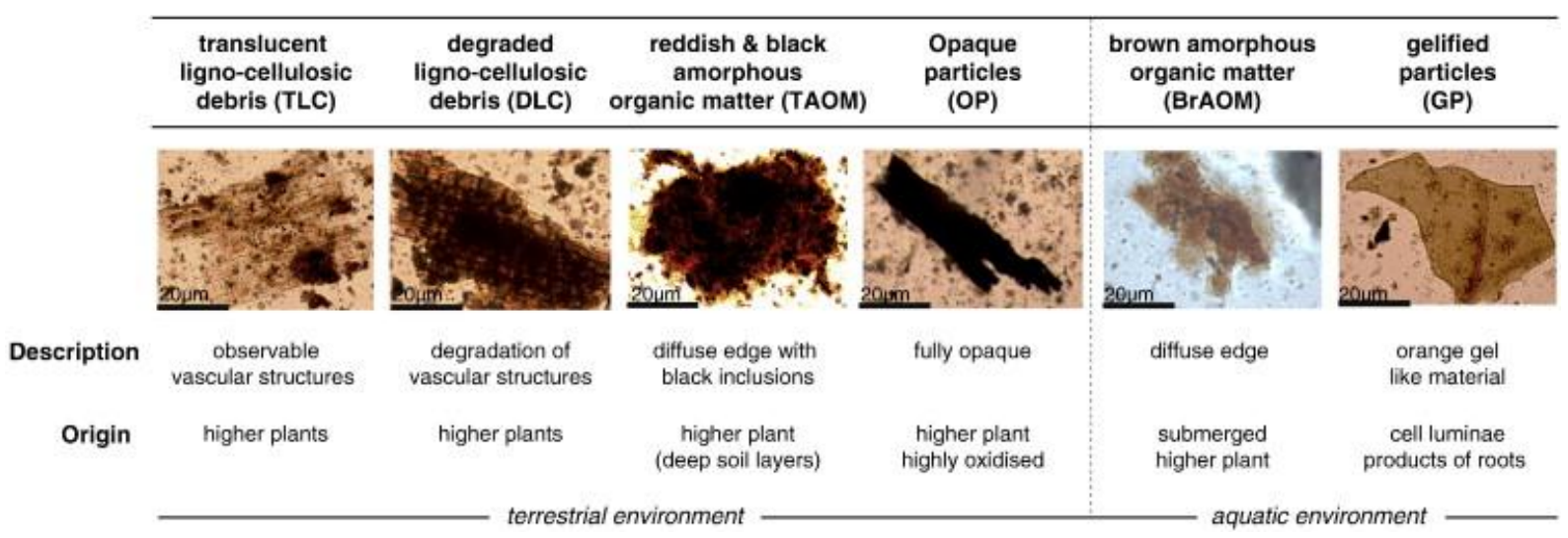

Fig. 2. : Main organic particles observed in BB2 and TK1 cores. Palynofacies classification derives from the review of Sebag et al. (2006c) 


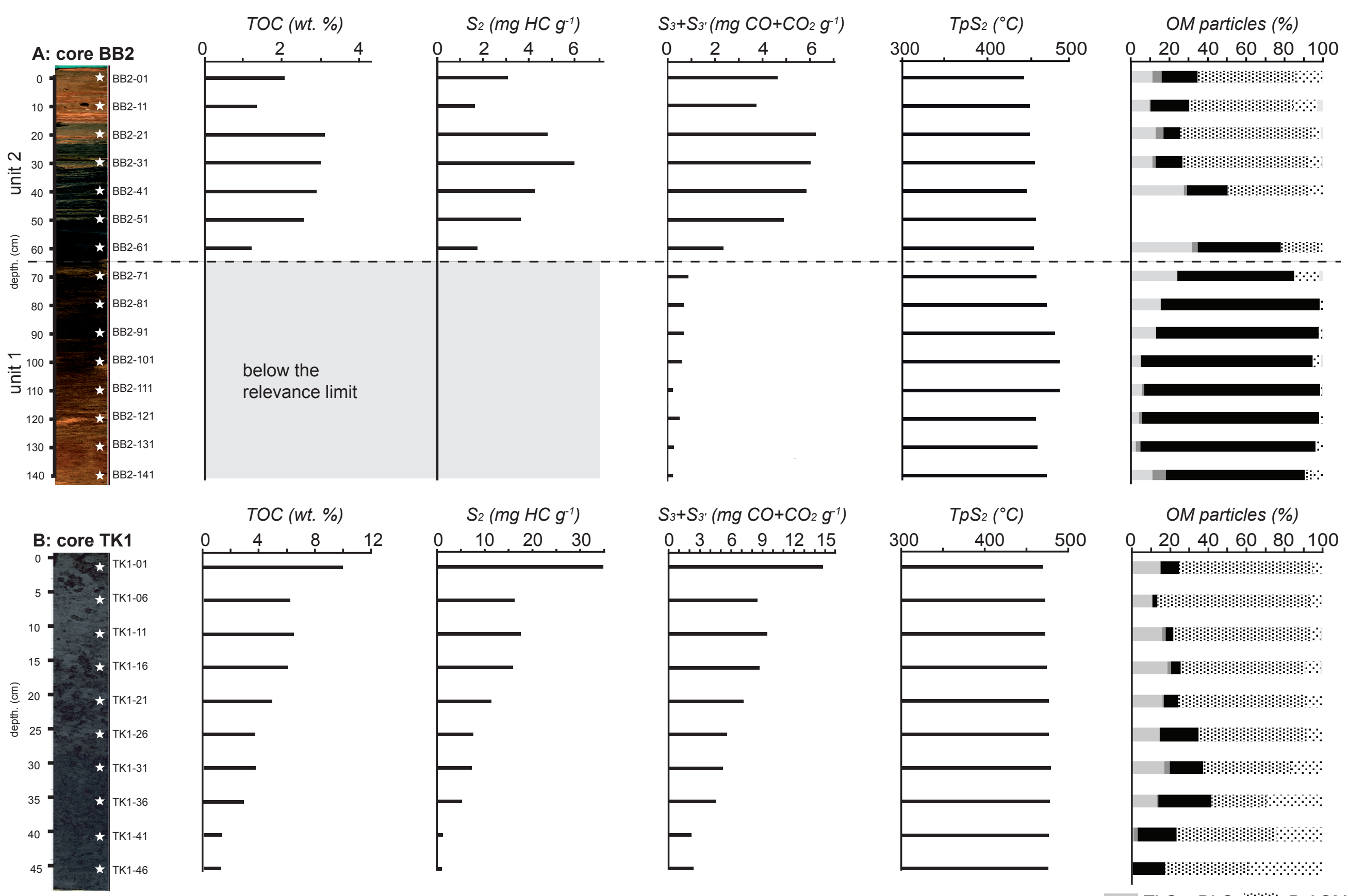

TLC + DLC BĐ! BrAOM

TAOM $\mathrm{W}$ GP

OP cuticles 


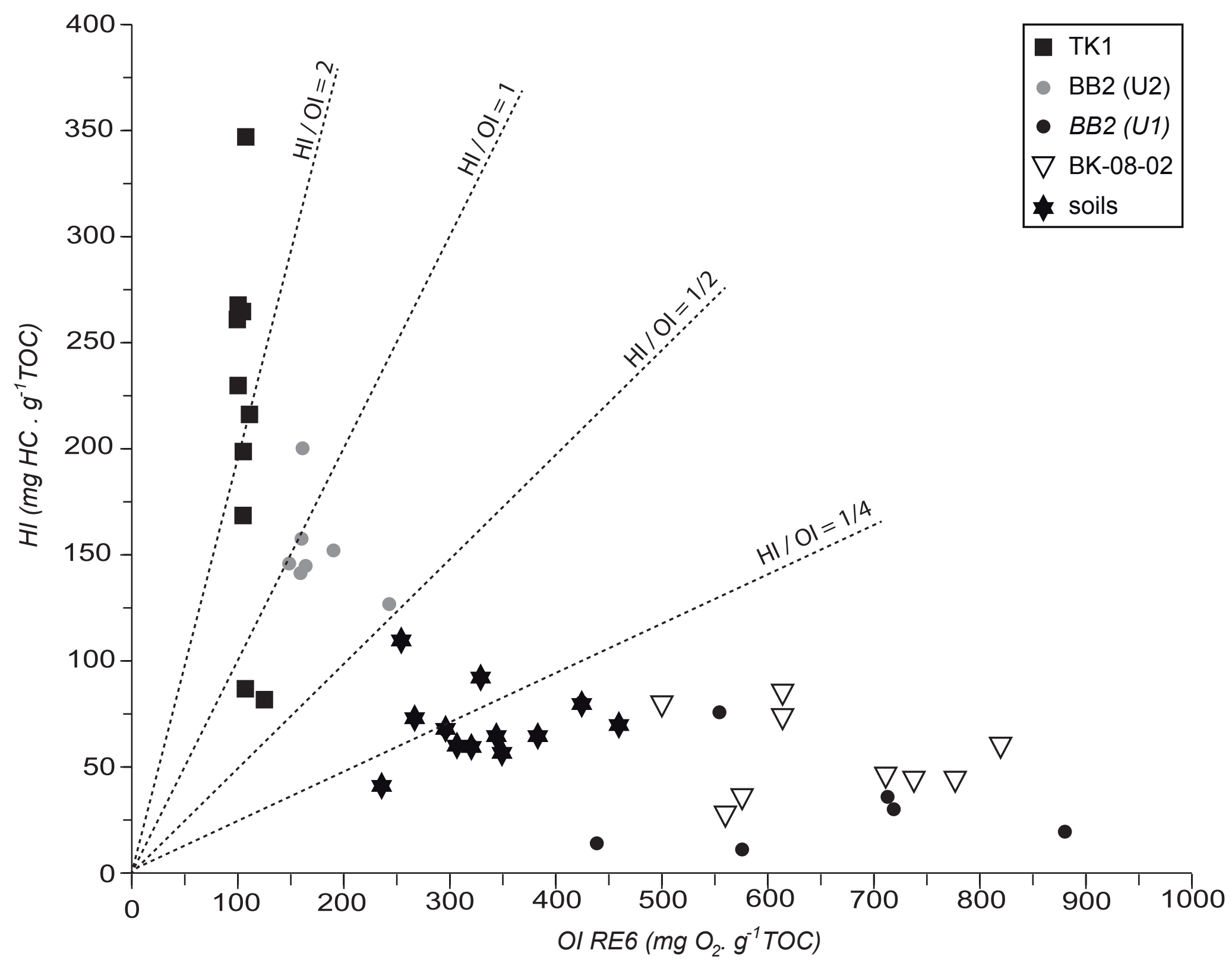



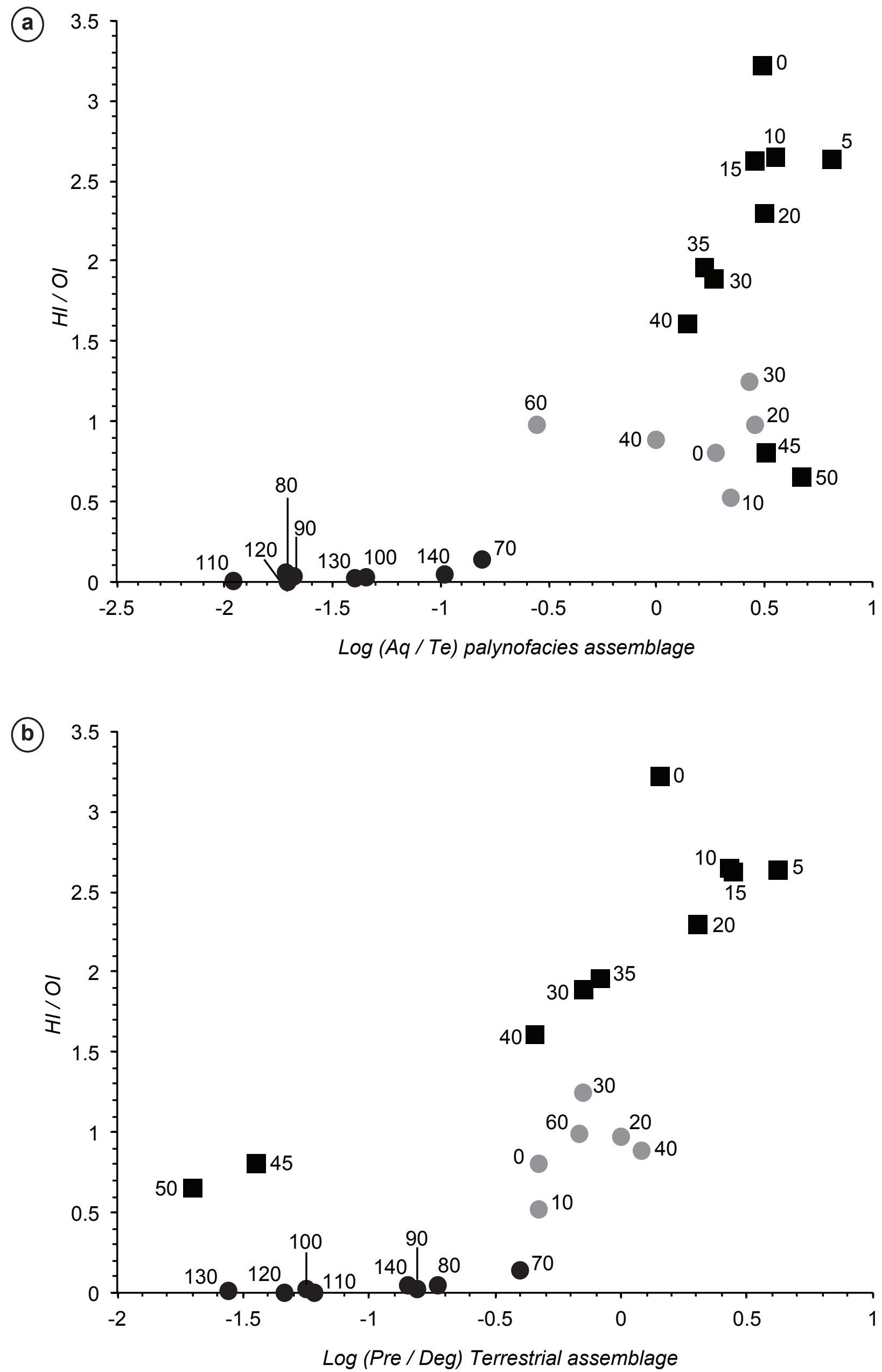


\begin{tabular}{|c|c|c|c|c|}
\hline Soils Taxonomy & Land Cover/land Use & Country & $\begin{array}{l}\text { topsoil OrgC } \\
\qquad(0-0.1 \mathrm{~m}) \\
\left(\mathrm{kg} \mathrm{C} \mathrm{m}^{-2}\right)\end{array}$ & References \\
\hline various & various & $\begin{array}{l}\text { Western } \\
\text { Africa }\end{array}$ & $1.10-1.20$ & Batjes, 2001 \\
\hline $\begin{array}{l}\text { Cambic } \\
\text { Arenosols }\end{array}$ & $\begin{array}{c}\text { cultivated surfaces (millet), } \\
\text { encrusted soils }\end{array}$ & Niger & 0.26 & this study \\
\hline Cambic arenosol & sparse savanna & $\begin{array}{l}\text { Northern } \\
\text { Sudan }\end{array}$ & $0.15-0.25$ & $\begin{array}{l}\text { Farage et al., } \\
2007\end{array}$ \\
\hline $\begin{array}{l}\text { Cambic } \\
\text { Arenosols }\end{array}$ & fallow & Senegal & 0.20 & Batjes, 2001 \\
\hline $\begin{array}{l}\text { Skeletic } \\
\text { Leptosols }\end{array}$ & tiger bush & Niger & 0.31 & this study \\
\hline $\begin{array}{l}\text { Psamentic } \\
\text { Paleustalfs }\end{array}$ & cultivated surfaces (millet) & Niger & $0.24-0.26$ & $\begin{array}{l}\text { Fofana et al., } \\
2008\end{array}$ \\
\hline $\begin{array}{l}\text { Psamentic } \\
\text { Paleustalfs }\end{array}$ & cultivated surfaces (millet) & Niger & 0.25 & $\begin{array}{l}\text { Buerkert and } \\
\text { Lamers, } 1999\end{array}$ \\
\hline Lixisols & $\begin{array}{c}\text { traditional parkland agroforestry, } \\
\text { improved agroforestry, degraded } \\
\text { land }\end{array}$ & Mali & 0.55 & $\begin{array}{l}\text { Takimoto et al., } \\
2009\end{array}$ \\
\hline $\mathrm{nc}$ & Savanna & Senegal & $0.37-0.50$ & Ringius, 2002 \\
\hline $\begin{array}{l}\text { Orthithionic } \\
\text { Gleysols }\end{array}$ & cultivated surfaces (rice) & Senegal & 1.39 & $\begin{array}{l}\text { Haefele et al., } \\
2004\end{array}$ \\
\hline Eutric Vertisols & cultivated surfaces (rice) & Senegal & 1.03 & $\begin{array}{l}\text { Haefele et al., } \\
2004\end{array}$ \\
\hline Arenosols & open wood savanna & Senegal & $0.38-0.73$ & $\begin{array}{l}\text { Elberling et al., } \\
2003\end{array}$ \\
\hline Arenosols & grass savanna & Senegal & 0.41 & $\begin{array}{l}\text { Elberling et al., } \\
2003\end{array}$ \\
\hline $\begin{array}{l}\text { Arenosols / } \\
\text { Regosols }\end{array}$ & grassland/isolated shrubs & Senegal & 0.29 & $\begin{array}{l}\text { Woomer et al., } \\
2004\end{array}$ \\
\hline $\begin{array}{l}\text { Arenosols / } \\
\text { Regosols }\end{array}$ & grassland/scattered shrubs & Senegal & 0.41 & $\begin{array}{l}\text { Woomer et al., } \\
2004\end{array}$ \\
\hline $\begin{array}{l}\text { Arenosols / } \\
\text { Regosols }\end{array}$ & shrubby grassland & Senegal & 0.63 & $\begin{array}{l}\text { Woomer et al., } \\
2004\end{array}$ \\
\hline $\begin{array}{l}\text { Arenosols / } \\
\text { Regosols }\end{array}$ & degraded grassland & Senegal & 0.29 & $\begin{array}{l}\text { Woomer et al., } \\
2004\end{array}$ \\
\hline nc (sandy soils) & $\begin{array}{c}\text { various cultivated surfaces from } \\
\text { Old Peanut basin }\end{array}$ & Senegal & 0.19 to 1.39 & $\begin{array}{l}\text { Tschakert et al., } \\
2004\end{array}$ \\
\hline $\begin{array}{l}\text { Arenosols to } \\
\text { Calcisols }\end{array}$ & $\begin{array}{l}\text { Senegal Peanut basin, G. } \\
\text { Senegalenis \& } \\
\text { P. Reticulum }\end{array}$ & Senegal & $0.40-0.60$ & $\begin{array}{l}\text { Lufafa et al., } \\
2008\end{array}$ \\
\hline Acrisols, Lixisol & Savanna & Northern & 1.10 to 1.30 & Volkoff et al., \\
\hline
\end{tabular}


and Luvisols

$\mathrm{nc}$
Benin

farmed parkland
Northern

Nigeria
1999

0.65 to 0.72 Farage et al., 2007

Table 1: OC Stocks in various Sahelian soils for 0.0- 0.1m depth. In italic, values are given according our density measurements of Millet cultivated area (Fofana et al., 2008); values of SOC content are initially given between $0-0.05 \mathrm{~m}$ for Elberling et al., 2003. For numerous studies SOC contents, initially given for $0.0-0.2$ or $0.3 \mathrm{~m}$, were arbitrary divided by 2 or 3, even if a strong variability in SOC content with topsoil occurs, in particular when soils are finely covered by cyanobacteria (e.g. Malam-Issa et al., 2001). 80\% of the SOC stock in western African soils is stored in the upper $0.0-0.3 \mathrm{~m}$ (Batjes, 2001). 


\begin{tabular}{|c|c|c|c|}
\hline Lakes / ponds & $\begin{array}{c}\mathrm{OC} \\
\text { accumulation rate } \\
\left(\mathrm{g} \mathrm{m}^{-2} \mathrm{yr}^{-1}\right)\end{array}$ & $\begin{array}{c}\text { Time scale } \\
\text { investigated } \\
(\mathrm{yr})\end{array}$ & References \\
\hline \multicolumn{4}{|l|}{ Sahelian belt } \\
\hline Bangou Bi and Kirey (Niger) & $104-213$ & 50 & This study \\
\hline Chad & 19 & Holocene & Einsele et al., 2001 \\
\hline \multicolumn{4}{|l|}{ rift valley and great Lakes } \\
\hline Sonachi & 9 & 175 & Verschuren, 1999 \\
\hline Naivasha & $12-62$ & 186 & Stoof-Leichsenring et al. 2011 \\
\hline Turkana & 162 & few hundreds & Barton and Torgersen 1988 \\
\hline Victoria & 16 & Holocene & Einsele et al. 2001 \\
\hline Kivu & 11 & 50 & Pasche et al. 2010 \\
\hline Tanganyika & 9 & $2000-2500$ & Einsele et al. 2001 \\
\hline Malawi & 16 & Holocene & Einsele et al. 2001 \\
\hline \multicolumn{4}{|l|}{ other tropical lakes } \\
\hline Kariba & 23 & $<50$ & Kunz et al. 2011 \\
\hline African tropical lakes & $1-45$ & $<25000$ & Giresse et al., 2010 \\
\hline lakes from Cameroon & $9-56$ & nc & Giresse et al. 1994 \\
\hline Taypi Chakakkota (Andes) & 10 & Holocene & Abbot et al. 1997 \\
\hline lakes from Brazil & $7-41$ & 500 & Turcq et al. 2002 \\
\hline \multicolumn{4}{|l|}{ reservoirs, ponds } \\
\hline World reservoirs & 400 & $\mathrm{nc}$ & Dean and Gorham 1998 \\
\hline aquaculture ponds & $28-333$ & $2-52$ & Boyd et al. 2010 \\
\hline Nasser-Nubia (Egypt-Sudan) & 260 & 1700 & Mullholland and Elwood, 1982 \\
\hline $\begin{array}{l}\text { Agriculturally-eutrophic } \\
\text { impoundments (Iowa, USA) }\end{array}$ & $148-17392$ & 100 & Downing et al. 2008 \\
\hline
\end{tabular}

Table 2: OC accumulation rates in various African and South American lakes. Sediments retained by dams for agricultural purposes are also given. For lake Kivu, the mean value is an average between white and brown layers (0-43cm depth). Lake Nasser-Nubia is considered as an agriculturally reservoirs. Kariba is an artificial lake along the river Zambezi. OC accumulation rate for lake Turkana was assessed with the equation (1). 